\title{
Structure and attribute modifications of spray-dried skim milk powder treated by DIC (instant controlled pressure drop) technology
}

\author{
Sabah MouniR ${ }^{1,2}$, Pierre Schuck ${ }^{3,4}$, Karim Allaf $^{1 *}$ \\ ${ }^{1}$ University of La Rochelle - Laboratory Transfer Phenomena \& Instantaneity in Agro-Industry \\ and Building LEPTIAB, Pole Science and Technology, Av. Michel Crépeau, \\ 17042 La Rochelle cedex 01, France \\ ${ }^{2}$ Faculty of Agriculture, Food Science Department, Zagazig University, Zagazig, Egypt \\ ${ }^{3}$ INRA, UMR1253, F-35042 Rennes, France \\ ${ }^{4}$ AGROCAMPUS OUEST, UMR1253, F-35042 Rennes, France
}

Received 11 May 2009 - Revised 11 January 2010 - Accepted 22 January 2010

Published online 30 March 2010

\begin{abstract}
Expanding the texture of granules can generally completely modify the functional behaviour of powder. The present study aimed to identify granule structure and quality attribute modifications of spray-dried skim milk powders after an instant controlled pressure-drop (DIC) treatment, which might be considered as a texturing stage inserted in a classic spray-drying process. Two versions of DIC, high air pressure (HAP-DIC) and low steam pressure (STEAM-DIC), were alternatively used. Response Surface Method experimental design was achieved with DIC pressure, treatment time, and moisture content as independent variables. The analyses of the technological, physical, and structural properties of untreated and DIC-textured powders were carried out and considered as response dependent variables. The results illustrated that whatever the type of DIC, the optimized DIC treatment implied a controlled increase in porosity, interstitial air volume, and compressibility, as well as specific surface area and reconstitution aptitude.
\end{abstract}

spray-dried powder / instant controlled pressure drop / bulk density / compressibility / porosity / solubility

\begin{abstract}
摘要 - DIC 处理方法对喷雾干燥脱脂乳粉结构和性能的影响。颗粒结构的膨胀可以很大 程度地改变乳粉的功能特性。本文探索了经瞬间控制压降 (DIC) 技术处理的喷雾干燥脱脂 乳粉的颗粒结构和品质性能的改变, 该工艺过程被认为是传统乳粉喷雾干燥过程中影响颗 粒形成的关键过程。分别交替使用高空气压力 (HAP-DIC) 和低蒸汽压力 (STEAM-DIC) 的两 种 DIC 处理, 以 DIC 的压力、处理时间、水分含量为自变量, 采用响应面法 (RSM) 进行试 验设计。通过对已喷干乳粉加湿的方法来调节水分含量。以未经 DIC 处理和 DIC 处理乳粉 的工艺、物理和结构特性参数为评价指标 (因变量) 进行响应面分析。研究结果表明, 在最 佳的 DIC 处理条件下, 干燥乳粉的孔隙率、孔隙间空气量、可压缩性、比表面积和乳粉的复 原性都有提高。
\end{abstract}

喷雾干燥乳粉 / 瞬间控制压降 / 松密度 / 可压缩性 / 孔隙率 / 溶解性

*Corresponding author (通讯作者): kallaf@univ-lr.fr 


\begin{abstract}
Résumé - Structure et modifications des propriétés d'une poudre de lait écrémé obtenue par atomisation après traitement par détente instantanée contrôlée (DIC). En raison d'un impact évident de l'expansion des granules sur le comportement fonctionnel des poudres, la présente étude visait à quantifier les modifications des caractéristiques d'une poudre de lait écrémé obtenue par atomisation classique générées par texturation par détente instantanée contrôlée (DIC). Deux versions de la technologie DIC ont alternativement été utilisées : la première par haute pression d'air (HAP-DIC) et la deuxième par faible pression de vapeur (STEAM-DIC). La poudre a subi une réhumidification par pulvérisation contrôlée. La méthode des plans d'expériences a été adoptée avec comme variables indépendantes la pression de la DIC, la durée du traitement et la teneur en humidité. L'analyse de la poudre non traitée et des échantillons différemment texturés par DIC a conduit à la quantification de diverses propriétés technologiques, physiques et structurelles considérées comme variables dépendantes dans la méthodologie de surface de réponse ainsi adoptée. Les résultats ont montré que quelle que soit la version adoptée, le traitement optimisé DIC impliquait une augmentation maîtrisée de la porosité, du volume interstitiel de l'air et de la compressibilité, ainsi que de la surface spécifique et des aptitudes à la reconstitution. La DIC pourrait ainsi être éventuellement considérée comme une étape de texturation à insérer dans une opération de séchage par atomisation.
\end{abstract}

poudre de lait / détente instantanée contrôlée / masse volumique apparente / compressibilité / porosité / solubilité

\section{INTRODUCTION}

Skim milk powder (SMP) is widely used as an ingredient in many formulated foods. Soups, sauces, confectionery, and bakery products all benefit from the functional properties provided by SMP. The powder can be tailored to a specific end-use by manipulating processing conditions. Milk powder manufacture is a common process currently carried out on a large scale. Spray drying involves atomizing the concentrate into fine droplets using either a spinning disk atomizer or a series of high pressure nozzles inside a large chamber, where a large part of the drying is carried out in a hot air flow (up to $200{ }^{\circ} \mathrm{C}$ ). The mean particle size is typically about $100 \mu \mathrm{m}$ diameter. In a welldesigned system, 15-30 $\mathrm{s}$ is a reasonable time for the passage of the sprayed particles through the drying zone. The milk droplets are cooled by evaporation and never reach the temperature of air. This is particularly important in handling heat-sensitive organic products, where the product temperature must not rise too high. This is why such treatment does not usually assure the stringent hygiene properties needed for well decontaminated sterilized finished powders. A final stage of drying (or "secondary" drying) takes place in a fluid bed or in a series of such beds, allowing powder to achieve a moisture content of about $4 \% \mathrm{db}$. On the other hand, the specific surface area (SSA) strictly depends on granulometry when the granule structure is compact; the only way to increase the SSA to $>200 \mathrm{~m}^{2} \cdot \mathrm{kg}^{-1}$ in the case of SMP to improve some important functional characteristics is thus to reduce the granule size to $<50 \mu \mathrm{m}$.

Usually the quality, functional characteristics, and behaviour of the final product have a bearing on the texture, which closely depends on the dehydration conditions. The shrinkage phenomenon may be coupled with the great gradient of moisture content; high temperature normally leads to complex thermal changes at the surface, which may be transformed into hard, impermeable skin. This is termed "case hardening". It reduces the rate of drying and produces granules with a dry surface and humid heart. It is minimized by controlling the drying conditions to prevent excessively high moisture gradients between the interior and the surface of the granule. 
To remedy such situations, additional texturing of hot-air-dried material by instant controlled pressure drop towards a vacuum DIC has been used in various cases. DIC technology was defined [4] as a high-temperature-short-time (HTST) treatment followed by an abrupt pressure drop towards vacuum (about $5 \mathrm{kPa}$ with a pressure drop speed $\left.>0.5 \mathrm{MPa} \cdot \mathrm{s}^{-1}\right)$. The last operation allows residual water to instantly autovaporize, inducing rapid cooling and controlled expansion of the product [1]. DIC treatment allows various heat-sensitive foodstuffs to expand while obtaining a very satisfactory quality [3]. This process greatly increases the exchange surface through controlled alveolation and intensifies the kinetics of the final drying stage. As a HTST treatment, DIC preserves the main sensorial attributes as well as the main nutritional and hygienic characteristics of the end product.

In powders, most functional properties are related to the total pore volume, porosity and mean pore radius, particle mean size and particle size distribution (presence of fine particles), and crystallization. They are, respectively, termed wettability, sinkability, dispersibility, and solubility [21]. In the spray-drying method, the air temperature, moisture, and speed as well as the behaviour and residence time of a droplet during drying have an important influence on the above-mentioned powder properties $[10,11,13]$. However, many of these properties are closely associated with SSA, which is normally affected by the particle size and the presence of pores [2, 14, 21]. Thus, in spray drying there are some general trends. Greater atomizer wheel speeds and nozzle pressures decrease droplet and therefore particle size, increasing bulk density $[16,20]$. Spherical particles can result in a low degree of interstitial air, as the small particles fill the void spaces between the larger ones. Irregular shaped particles and agglomerates can increase the bulk density.

Recently, Mounir and Allaf [15] proposed a new process of spray drying which involves inserting a texturing treatment by DIC between conventional spray drying and final fluidized-bed drying. As the main functional properties closely depend on the SSA of the powder, increasing the SSA is attempted in order to improve the quality. However, in order to avoid flow and other problems linked to the presence of fine particles, the size of the granules has to be greater than 100 or even $150 \mu \mathrm{m}$. By inserting the DIC treatment it is possible both to expand the granule and to create internal pores, thus breaking the close relationship between SSA and particle size. The aim of the present paper was to study the main effects of DIC operative conditions on structural, physical, and reconstitution characteristics in the case of SMPs. Two low-temperature versions of DIC treatment were considered: high-air-pressure (HAP-DIC) and low steam pressure (STEAM-DIC).

\section{MATERIALS AND METHODS}

\subsection{Raw materials: powders}

Trials were carried out on skim milk "low heat" powder manufactured at the INRA Joint Research Unit "Science and Technology of Milk and Egg", Rennes, France. Table I shows the initial chemical composition. The packed and aerated bulk densities as well as the SSA of this powder were determined to be $476 \mathrm{~kg} \cdot \mathrm{m}^{-3}$, $429 \mathrm{~kg} \cdot \mathrm{m}^{-3}$, and about $109 \mathrm{~m}^{2} \cdot \mathrm{kg}^{-1}$, respectively [15]; its mean granule diameter was about $100 \mu \mathrm{m}$ (Fig. 6).

As the texturing effect of DIC is a function of the amount of vapour generated by autovaporization as well as the glass transition, and both depend strictly on the initial water content of the material, the powder humidity was adjusted between $4 \% \mathrm{db}$ and $22 \% \mathrm{db}$ depending on the experimental design for DIC treatment. However, in the present work it was not so easy to control 
Table I. Physical and chemical characterization of classical spray-dried skim milk.

\begin{tabular}{llcc}
\hline & & \multicolumn{2}{c}{ Sample } \\
\cline { 3 - 4 } & & $\mathrm{H} 1$ & $\mathrm{H} 2$ \\
\hline Powder & $\begin{array}{l}\text { Casein } \\
\left(\mathrm{g} \cdot \mathrm{kg}^{-1}\right)\end{array}$ & 250.1 & 246.2 \\
& $\begin{array}{l}\text { Whey protein } \\
\left(\mathrm{g} \cdot \mathrm{kg}^{-1}\right)\end{array}$ & 66.8 & 65.9 \\
& $\begin{array}{l}\text { Water content } \\
(\% \mathrm{db})\end{array}$ & 6.0 & 7.5 \\
& $a_{\mathrm{w}}$ & 0.34 & 0.41 \\
Spray-drying & $T_{\text {inlet }}\left({ }^{\circ} \mathrm{C}\right)$ & 140 & 110 \\
temperature & $T_{\text {outlet }}\left({ }^{\circ} \mathrm{C}\right)$ & 64 & 47 \\
\hline & & &
\end{tabular}

the moisture content of powder by controlling spray-drying conditions (air temperature, speed of flow, and humidity content), and it was much easier to do it by rewetting the dried milk samples or placing the powder in a high moisture atmosphere. A follow-up of mass allowed the sample to be taken out, stopping the rewetting process once the desired water content was reached. They were then stored at $6{ }^{\circ} \mathrm{C}$ for $24 \mathrm{~h}$ in an airtight-seal pack in order to ensure good homogenization of the water within the powder.

\subsection{Treatment equipment}

Figure 1 shows the operational protocol used in different trials. The setup for the DIC treatment $[3,4]$ comprises three main parts (Fig. 2):

- A $5 \mathrm{~L}$ processing vessel (1), where steam or gas pressure can be established up to $1 \mathrm{MPa}$.

- A vacuum system, which is mainly a vacuum tank (2) with a volume 120 times greater than that of the processing reactor, and an adequate vacuum pump capable of reaching and keeping the vacuum level constant at
$5 \pm 0.1 \mathrm{kPa}$ in all our experiments just before dropping the pressure.

- An abrupt pneumatic valve (3) that assures the connection/separation between the vacuum tank and the processing vessel. It can be opened in $<0.2 \mathrm{~s}$, which ensures the "instant" pressure drop within the reactor.

Samples of $\sim 60 \mathrm{~g}$ of loose, wetted dairy powders were first placed in the DIC treatment vessel. The treatment consisted of setting up a first vacuum stage $(5 \mathrm{kPa})$ and then injecting gas at a predefined pressure (between 0.02 and $1 \mathrm{MPa}$ ) and maintaining it for a predefined time (between 2 and $60 \mathrm{~s}$ ); the gas we used was compressed air in the case of HAP-DIC and lightly overheated steam in the case of STEAM-DIC. By dropping the pressure abruptly $(\Delta P / \Delta t>$ $\left.0.5 \mathrm{MPa} \cdot \mathrm{s}^{-1}\right)$ towards vacuum, instant autovaporization occurs, inducing texturing and "instant" cooling of the treated material. To intensify the cooling process of the powder surface, a weak airflow was introduced and released towards vacuum.

After DIC treatment, convective drying was carried out in an independent drier with a stream of dry air at $50{ }^{\circ} \mathrm{C}$; the dried samples with water content $3 \% \mathrm{db}$ were then recovered and ready for characterization.

In order to achieve a relevant experimental study on the impact of various operating parameters and to optimize the DIC treatment, a five-level central composite rotatable experimental design method was adopted. In this study, three DIC operating parameters were studied: air or steam pressure $(P)$, processing time $(t)$, and the initial water content of the powder $(W)$, while keeping the other operating parameters constant. The experiments were run at random to minimize the effects of unexpected variability of responses due to unrelated factors. DIC treatment experiments were then carried out using the operating conditions as described in Tables II and III. 


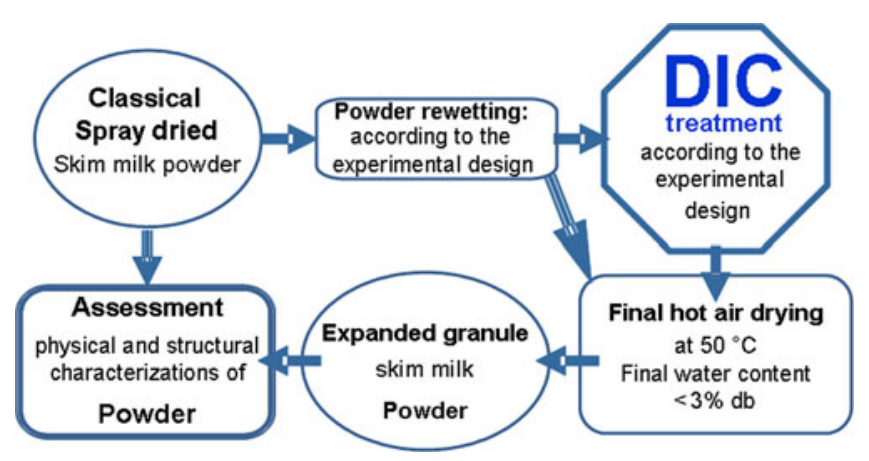

Figure 1. Operating treatment protocol.

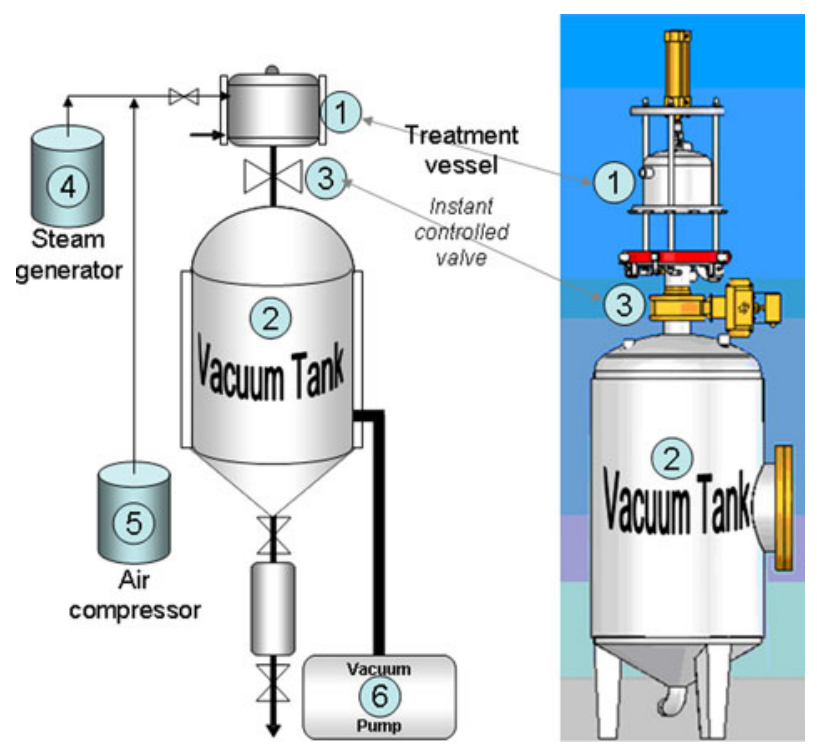

Figure 2. Schematic presentation of DIC reactor: (1) treatment vessel; (2) vacuum tank; (3) controlled instant pressure-drop valve; (4) generator of steam under pressure; (5) air compressor; and (6) vacuum pump.

The surface responses were determined through the analysis design procedure of Statgraphics Plus software for Windows (1994, version 4.1, Levallois-Perret, France).

\subsection{Characterization protocol}

Samples characterization was normally performed after cooling and storage at ambient conditions for $24 \mathrm{~h}$ in an airtightseal pack in order to ensure good homogenization of the powder. Water content, expressed as percentage dry basis $(\% \mathrm{db})$, was determined by the desiccation method in an Infrared Dryer/Moisture analyzer (Mettler Toledo PE360 LP16 balance Bishop International Akron, OH, USA). For calibration, the measurement of water 
Table II. Experimental design of texturing SMP by HAP-DIC treatment.

\begin{tabular}{lccr}
\hline Points & Air pressure $(\mathrm{MPa})$ & Water content $(\% \mathrm{db})$ & Time $(\mathrm{s})$ \\
\hline$+\alpha$ & $0.8 \pm 0.02$ & $22 \pm 1$ & $30 \pm 2$ \\
$-\alpha$ & $0.2 \pm 0.02$ & $4 \pm 1$ & $4 \pm 2$ \\
Central point 0 & $0.5 \pm 0.02$ & $13 \pm 1$ & $17 \pm 2$ \\
+1 & $0.7 \pm 0.02$ & $18 \pm 1$ & $25 \pm 2$ \\
-1 & $0.3 \pm 0.02$ & $8 \pm 1$ & $9 \pm 2$ \\
\hline
\end{tabular}

Table III. Experimental design of texturing SMP by STEAM-DIC treatment.

\begin{tabular}{lccr}
\hline Points & Steam pressure $(\mathrm{MPa})$ & Water content $(\% \mathrm{db})$ & Time $(\mathrm{s})$ \\
\hline$+\alpha$ & $0.07 \pm 0.002$ & $22 \pm 1$ & $55 \pm 2$ \\
$-\alpha$ & $0.01 \pm 0.002$ & $4 \pm 1$ & $5 \pm 2$ \\
Central point 0 & $0.04 \pm 0.002$ & $13 \pm 1$ & $30 \pm 2$ \\
+1 & $0.057 \pm 0.002$ & $18 \pm 1$ & $44 \pm 2$ \\
-1 & $0.023 \pm 0.002$ & $8 \pm 1$ & $16 \pm 2$ \\
\hline
\end{tabular}

content with a drying oven at $105^{\circ} \mathrm{C}$ during $24 \mathrm{~h}$ was carried out three times: after rewetting, just before DIC treatment, and after final drying.

The apparent bulk density "aerated bulk density" $\rho_{\mathrm{a}}\left(\mathrm{kg} \cdot \mathrm{m}^{-3}\right)$ was calculated by measuring the volume occupied by a given powder mass, and the bulk packed density $\rho_{\mathrm{p}}$ $\left(\mathrm{kg} \cdot \mathrm{m}^{-3}\right)$ was obtained following 100 successive jerks. Powder densities $\rho_{\mathrm{a}}$ and $\rho_{\mathrm{p}}$ were determined and used to identify "compressibility" $\chi(\%)$, which describes the aptitude of the powder to lose volume by packing or tapping according to Carr's formula [6]:

$$
\chi \%=\frac{\rho_{\mathrm{p}}-\rho_{\mathrm{a}}}{\rho_{\mathrm{p}}} .
$$

A Pentapyc ${ }^{\mathrm{TM}}$ 5200e Gas Pycnometer was used for determining the intrinsic (or true, skeletal) density $\left(\mathrm{kg} \cdot \mathrm{m}^{-3}\right)$. The densities $\rho_{\text {int }}$ and $\rho_{\mathrm{p}}$ were used to identify the interstitial air volume, which is defined as the difference between the volume of a given mass $(100 \mathrm{~g})$ of tapped powder and the intrinsic (true) volume of the same mass of particles [5]. The interstitial air volume was calculated according to the NIRO method [17]:

$$
V_{\mathrm{ai}}=0.110^{6}\left(\frac{1}{\rho_{\mathrm{p}}}-\frac{1}{\rho_{\mathrm{int}}}\right) .
$$

Bed porosity was calculated according to the equation:

$$
\varepsilon=1-\left(\frac{\rho_{\mathrm{a}}}{\rho_{\mathrm{int}}}\right) .
$$

The reconstitution properties, which are wettability, dispersibility, and solubility, were determined at the INRA Joint Research Unit "Science and Technology of Milk and Egg", Rennes, France, according to the NIRO method [17]. Wettability is defined as the wetting time expressed in seconds for $10 \mathrm{~g}$ of skim milk when dropped on $100 \mathrm{~mL}$ water at $20^{\circ} \mathrm{C}$. Dispersibility of skim milk is the percentage of dissolved powder after stirring $10 \mathrm{~g}$ of powder in $100 \mathrm{~mL}$ water at $20{ }^{\circ} \mathrm{C}$ for $20 \mathrm{~s}$ and 
pouring the reconstituted milk through a $150 \mu \mathrm{m}$ sieve.

The FIL method [8] was followed to determine the insolubility index of SMP. It evaluates the ability of the powder to be broken into particles to enable it to pass through a sieve with defined diameter pores.

Measurements of granulometry were achieved through the statistical distribution of granule sizes, thanks to a vertical vibration sieving system ANALYSETTE PRO3 Fritsch (Idar-Oberstein, Germany) used with $100 \mathrm{~g}$ of representative powder, with a duration of $5 \mathrm{~min}$. Sieves used were 50 , 71, 200, 600, 1000, 1400, and $1700 \mu \mathrm{m}$; an Adventurer Pro laboratory balance (Ohaus, Viroflay, France) with a precision of $0.01 \mathrm{~g}$ was used for weighing.

As the surface accessible to gas or liquid molecules, the SSA is usually measured by quantifying the gas adsorbed per unit mass and is expressed in $\mathrm{m}^{2} \cdot \mathrm{kg}^{-1}$. A "Surface Area Analyser" QSURF system (ThermoFinnigan, Villebon-sur-Yvette, France) was used to determine the SSA of the powder. The principle is based on gas adsorption at low temperature (similar to BET). A sample of $\sim 0.8 \mathrm{~g}$ (in order not to exceed $66 \%$ of cell volume) was degassed for at least $6 \mathrm{~h}$ at room temperature to avoid any thermal degradation. The adsorption gas was the nitrogen $\mathrm{N}_{2}$, and the measurement was usually duplicated.

\section{RESULTS AND DISCUSSION}

\subsection{Physical characterization}

Whatever the skim milk sample (spray dried, HAP-DIC, or STEAM-DIC), the intrinsic sample density $\rho_{\text {int }}$ was constant at $1336 \pm 2 \mathrm{~kg} \cdot \mathrm{m}^{-3}$. Whatever the type of DIC-texturing treatment, the bulk density of SMP was significantly influenced by either air or steam pressures (Figs. 3a and 3b). To compare the bulk densities, samples were systematically dried up to $3 \% \mathrm{db}$. The bulk density of textured SMP $\left(\rho_{\mathrm{a}}\right.$ between 335 and $390 \mathrm{~kg} \cdot \mathrm{m}^{-3}$ ) was lower than those of rewetted-dried up to $3 \% \mathrm{db}$ $\left(\rho_{\mathrm{a}} 464 \mathrm{~kg} \cdot \mathrm{m}^{-3}\right)$ and classical spray-dried powders $\left(\rho_{\mathrm{a}} 429 \mathrm{~kg} \cdot \mathrm{m}^{-3}\right)$, as shown in Table IV. On the other hand, comparing the two versions of DIC-texturing, the bulk density of SMP treated by STEAM-DIC (between 335 and $387 \mathrm{~kg} \cdot \mathrm{m}^{-3}$ ) was lower than that of the powder treated by HAPDIC $\left(\rho_{\mathrm{a}}\right.$ about $\left.390 \mathrm{~kg} \cdot \mathrm{m}^{-3}\right)$; it means a higher expansion rate with the STEAMDIC treatment because the volume of vapour generated by the autovaporization when the pressure drops is much higher than that of expanded air obtained by dropping the pressure from the HAP-DIC treatment.

The decrease in the aerated bulk density of DIC-textured powder is due to the enlargement of granules creating interparticle voids; the presence of occluded air/vacuoles in the irregularly shaped particles consequently results in a larger bulk volume.

The regression models of aerated bulk density of textured powder were determined for HAP-DIC texturing (with $R^{2}=0.75$ ) and for STEAM-DIC texturing (with $\left.R^{2}=0.70\right)$, respectively, as follows:

$$
\text { HAP-DIC: }
$$

$$
\begin{aligned}
\rho_{\mathrm{a}}= & 404+57 P+2.2 W+0.7 t \\
& -142 P^{2}+4 P W-2 P t \\
& -0.2 W^{2}+0.04 W t-0.005 t^{2},
\end{aligned}
$$

STEAM-DIC:

$$
\begin{aligned}
\rho_{\mathrm{a}}= & 453-1462 P-3.5 W+2.5 t \\
& +1859 P^{2}-101 P W-12 P t \\
& +0.33 W^{2}-0.07 W t-0.06 t^{2} .
\end{aligned}
$$

The "bulk packed" density $\rho_{\mathrm{p}}$ means the ability of the powder to lose a part of its volume by compressing or tapping. With regard to DIC treatments, the bulk packed 

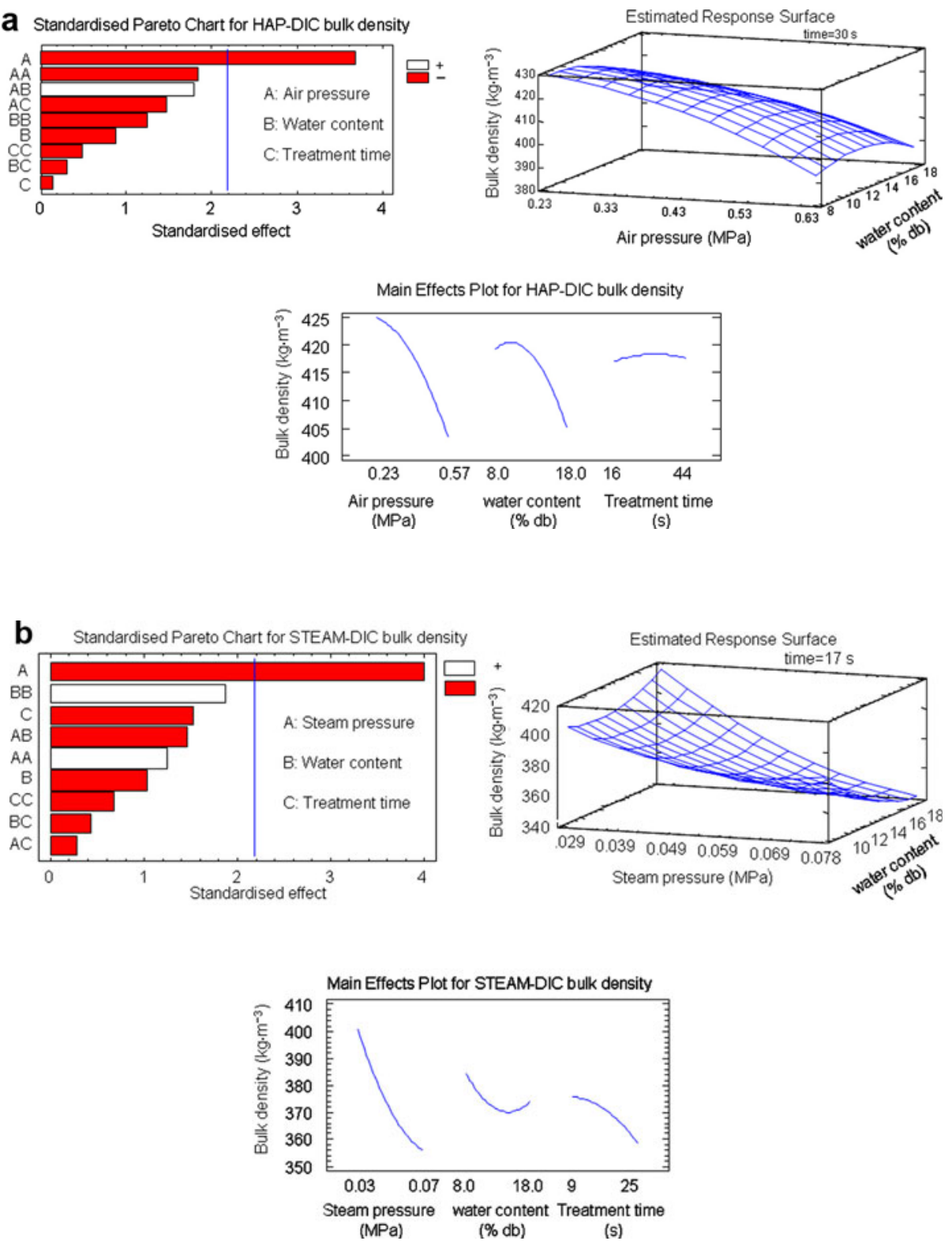

Figure 3. Bulk density of SMP: (a) HAP-DIC textured powder and (b) STEAM-DIC textured powder. 
Table IV. Bulk density of SMP: DIC-texturing powder, rewetted powder, and classical spray-dried powder.

\begin{tabular}{lcc}
\hline SMP & $\rho_{\mathrm{a}}\left(\mathrm{kg} \cdot \mathrm{m}^{-3}\right)$ & $\rho_{\mathrm{p}}\left(\mathrm{kg} \cdot \mathrm{m}^{-3}\right)$ \\
\hline Classical spray-dried powder (control) & 429 & 476 \\
Rewetted powder at $W=13 \% \mathrm{db}$ & 464 & 481 \\
Rewetted powder at $W=18 \% \mathrm{db}$ & 464 & 481 \\
HAP-DIC powder $P=0.57 \mathrm{MPa} ; W=8 \% \mathrm{db} ; t=44 \mathrm{~s}$ & 389 & 448 \\
HAP-DIC powder $P=0.57 \mathrm{MPa} ; W=18 \% \mathrm{db} ; t=16 \mathrm{~s}$ & 390 & 456 \\
STEAM-DIC powder $P=0.050 \mathrm{MPa} ; W=13 \% \mathrm{db} ; t=17 \mathrm{~s}$ & 335 & 454 \\
STEAM-DIC powder $P=0.08 \mathrm{MPa} ; W=13 \% \mathrm{db} ; t=17 \mathrm{~s}$ & 387 & 435 \\
\hline
\end{tabular}

density $\rho_{\mathrm{p}}$ after specific compaction had a similar behaviour to aerated bulk density, but with closer values; thus for DIC-textured powders, the bulk packed density $\rho_{\mathrm{p}}$ $\left(448-456 \mathrm{~kg} \cdot \mathrm{m}^{-3}\right.$ for HAP-DIC and $435-454 \mathrm{~kg} \cdot \mathrm{m}^{-3}$ for STEAM-DIC) was slightly lower than that of rewetted $\left(\rho_{\mathrm{p}}=481 \mathrm{~kg} \cdot \mathrm{m}^{-3}\right)$ or conventional spraydried SMP $\left(\rho_{\mathrm{p}}=476 \mathrm{~kg} \cdot \mathrm{m}^{-3}\right)$. This observation correlates with that of Walton and Mumford's hypothesis [21], stipulating that the rearrangement of irregular shaped particles allows the fine particles to fill the interparticle large space voids, inducing a low degree of interstitial air.

In both texturing cases of STEAM-DIC and HAP-DIC, the higher the pressure, the lower the packed density (Figs. $4 \mathrm{a}$ and $4 \mathrm{~b}$ ); however, in the case of HAP-DIC, the treatment time also had a very significant effect. The regression models of bulk packed density of textured powder were determined, respectively, for HAPDIC texturing (with $R^{2}=0.82$ ) and for STEAM-DIC texturing (with $R^{2}=0.76$ ), as follows:

HAP-DIC:

$$
\begin{aligned}
\rho_{\mathrm{p}}= & 493-20 P+2 W-0.56 t \\
& -93 P^{2}-11 P W+4.7 P t \\
& +0.3 W^{2}-0.125 W t \\
& -0.009 t^{2}
\end{aligned}
$$

STEAM-DIC:

$$
\begin{aligned}
\rho_{\mathrm{p}}= & 529.2-9930 P-4.99 W \\
& +2.57 t+10600 P^{2}-434 P W \\
& -5 P t+0.2 W^{2}+0.2 W t \\
& -0.1 t^{2} .
\end{aligned}
$$

Finally, the compressibility $\chi$, which decreased after rewetting, generally increased after DIC-texturing. The values of compressibility $\chi$ of SMP were $15 \%$ for powder textured by HAP-DIC $(P=$ $0.57 \mathrm{MPa} ; \quad W=18 \% \mathrm{db} ; t=16 \mathrm{~s})$ and $21 \%$ by STEAM-DIC $(P=0.030 \mathrm{MPa}$; $W=18 \% \mathrm{db} ; t=25 \mathrm{~s}$ and $P=0.050 \mathrm{MPa}$; $W=13 \% \mathrm{db} ; t=17 \mathrm{~s}$ ); they were $3.4 \%$ and $9.9 \%$ for rewetted powder and conventional spray-dried skim-milk powder, respectively.

Comparing the two versions of DIC-texturing (Figs. 5a and 5b), the treatment time and the initial water content had a significant effect on the compressibility of powder treated by HAP-DIC; however, in the case of STEAM-DIC, the steam pressure had a slight impact, and the other parameters ( $t$ and $W$ ) had a negligible effect on compressibility. On the other hand, the compressibility of powder textured by STEAMDIC was higher than that of powder treated by HAP-DIC. 


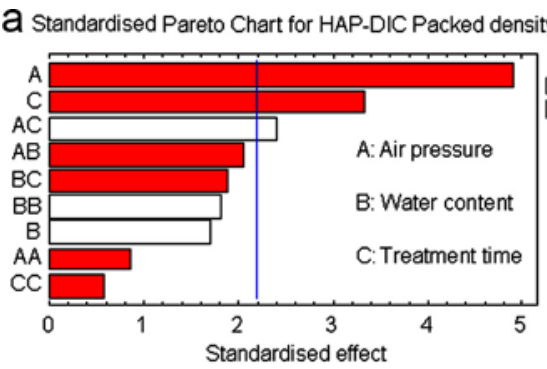

Estimated Response Surface
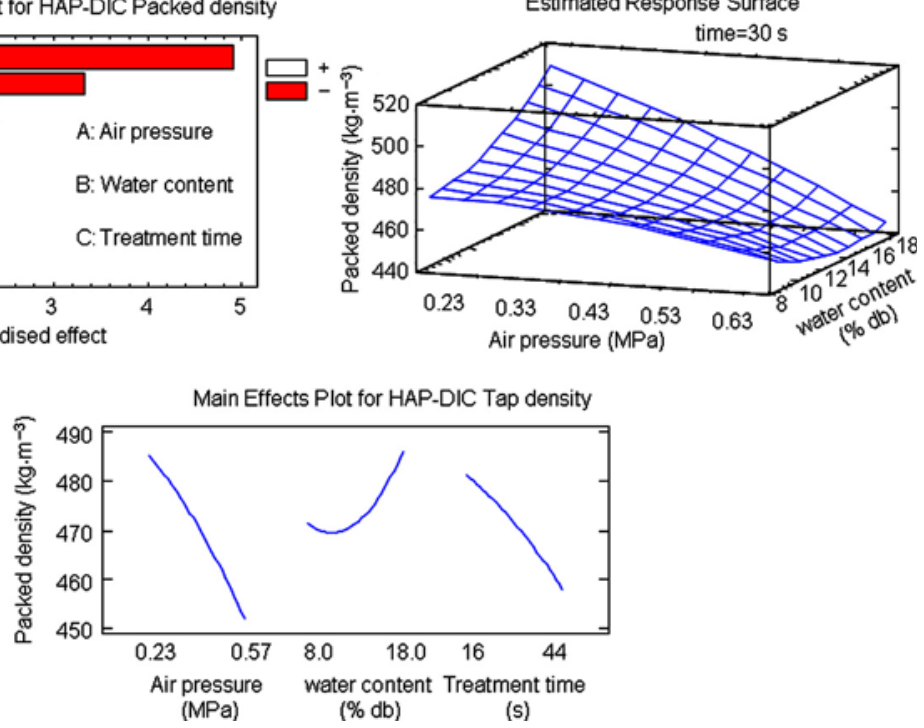

b Standardised Pareto Chart for STEAM-DIC Packed density
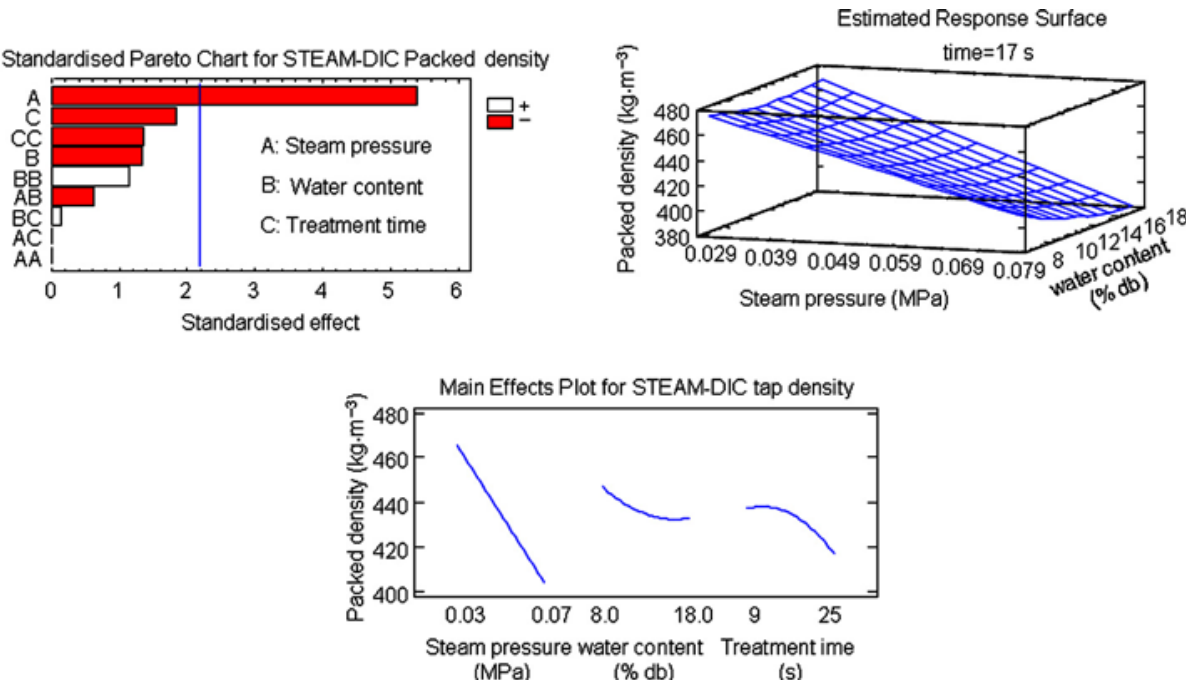

Figure 4. Packed density of SMP: (a) HAP-DIC textured powder and (b) STEAM-DIC textured powder. 
a Standardised Pareto Chart for HAP-DIC compressibilty
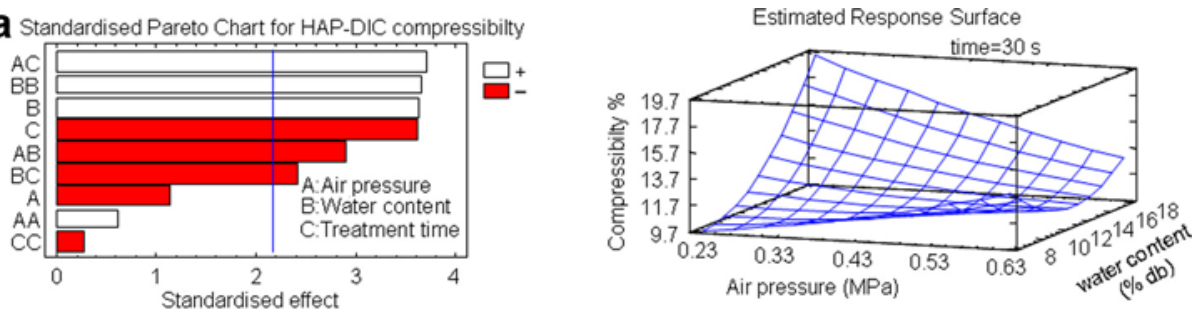

Main Effects Plot for HAP-DIC compressibilty

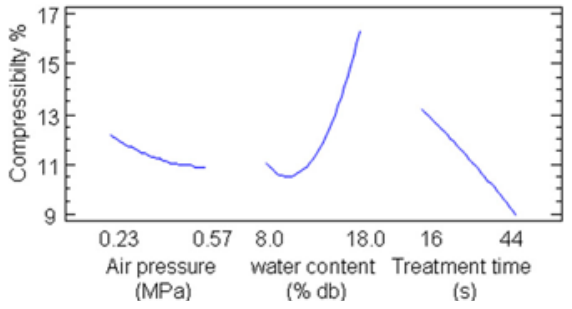

b Standardised Pareto Chart for STEAM-DIC compressibility

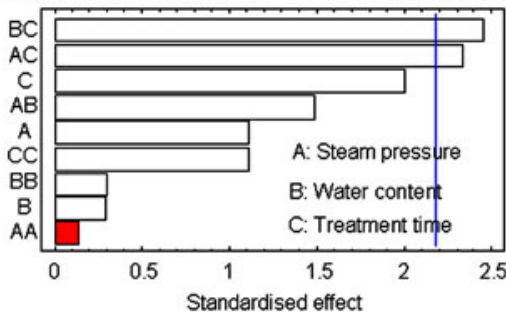

Estimated Response Surface
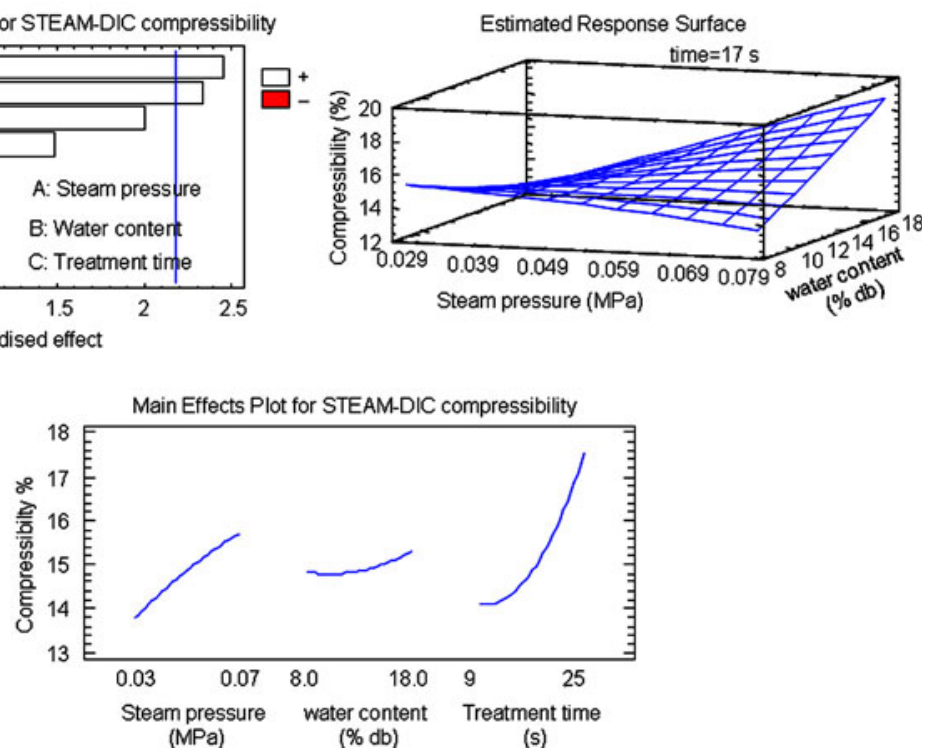

Figure 5. Compressibility of SMP: (a) HAP-DIC textured powder and (b) STEAM-DIC textured powder. 


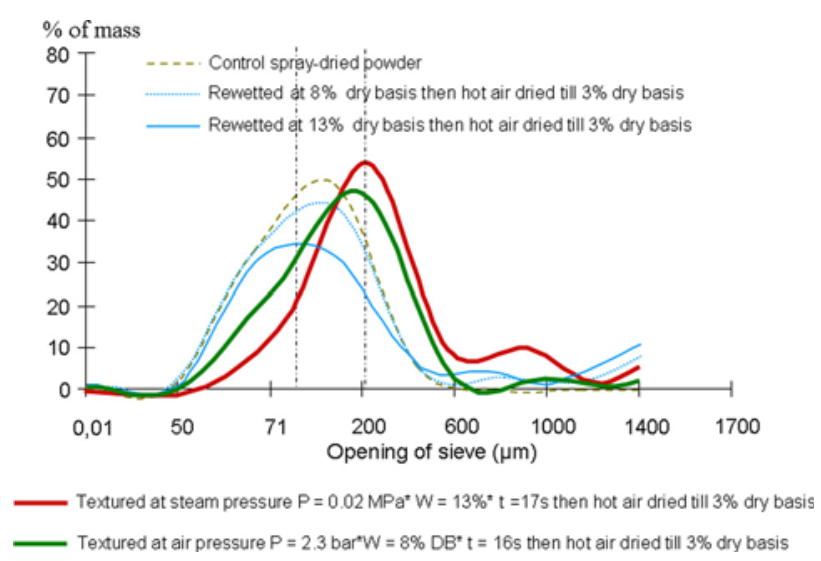

Figure 6. Impact of HAP-DIC and STEAM-DIC texturing on evolution of particle size distribution of SMP.

The empirical model for compressibility of HAP-DIC powder, with $R^{2}=0.84$, is

$$
\begin{aligned}
\chi \%= & 18.5-14.4 P-0.19 W \\
& -0.244 t+11.1 P^{2} \\
& -2.62 P W+1.2 P t \\
& +0.098 W^{2}-0.0264 W t \\
& -0.0006 t^{2} .
\end{aligned}
$$

But for STEAM-DIC texturing, the regression model of compressibility was given with $R^{2}=0.69$ :

$$
\begin{aligned}
\chi \%= & -25.73+466 P+5.17 W \\
& +0.53 t-1706 P^{2}-49.4 P W \\
& +18.5 P t+0.03 W^{2}-0.18 W t \\
& +0.013 t^{2} .
\end{aligned}
$$

\subsection{Microstructural analysis}

Figure 6 shows notable evolution of particle size distribution of HAP-DIC and STEAM-DIC SMP, respectively, compared to the conventional spray-dried powder. The obtained results prove that the texturing of powder by DIC results in reducing the amount of fine powder $(50$ and $71 \mu \mathrm{m})$ and increasing the mean size $(200 \mu \mathrm{m}$ as compared to $100 \mu \mathrm{m}$ for untreated spraydried powder), which is explained by the expanding and swelling of granules.

Figures $7 \mathrm{a}$ and $7 \mathrm{~b}$ show the evolution of powder porosity. Whether the DIC-texturing was the HAP-DIC or the STEAM-DIC version, the evolution of powder bed porosity depended on the pressure: the higher the air or steam pressure, the higher the bed porosity as a result of the greater expansion of granules [15]. The high value of porosity explains the low values of bulk density and the high percentages of compressibility for textured powders; indeed, compressibility increased when the external and internal porosity increased. As illustrated in Figures 7a and $7 \mathrm{~b}$, the porosity was influenced by both the texturing pressure and the initial water content of the powder. Porosity ranged from $71 \%$ to $75 \%$ for powders textured by HAP-DIC and STEAM-DIC, respectively, compared with $66 \%$ and $69 \%$ for rewetted and classical spray-dried powders, respectively.

The regression models of the porosity of textured powder were determined 
a Standardised Pareto Chart for HAP-DIC bed porosity

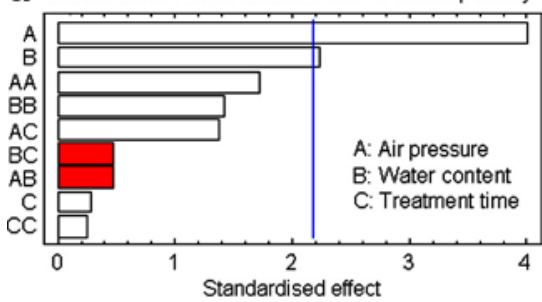

Estimated Response Surface

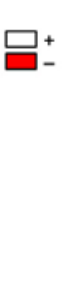

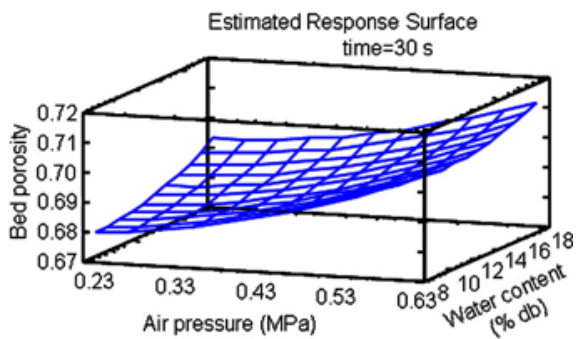

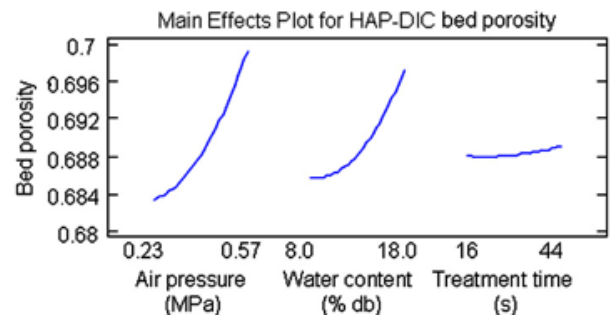

b Standardised Pareto Chart for STEAM-DIC bed porosity

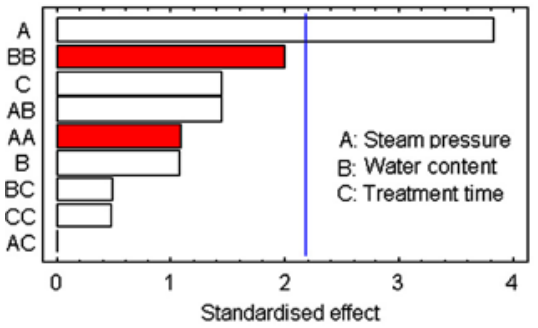

Estimated Response Surface time $=17 \mathrm{~s}$
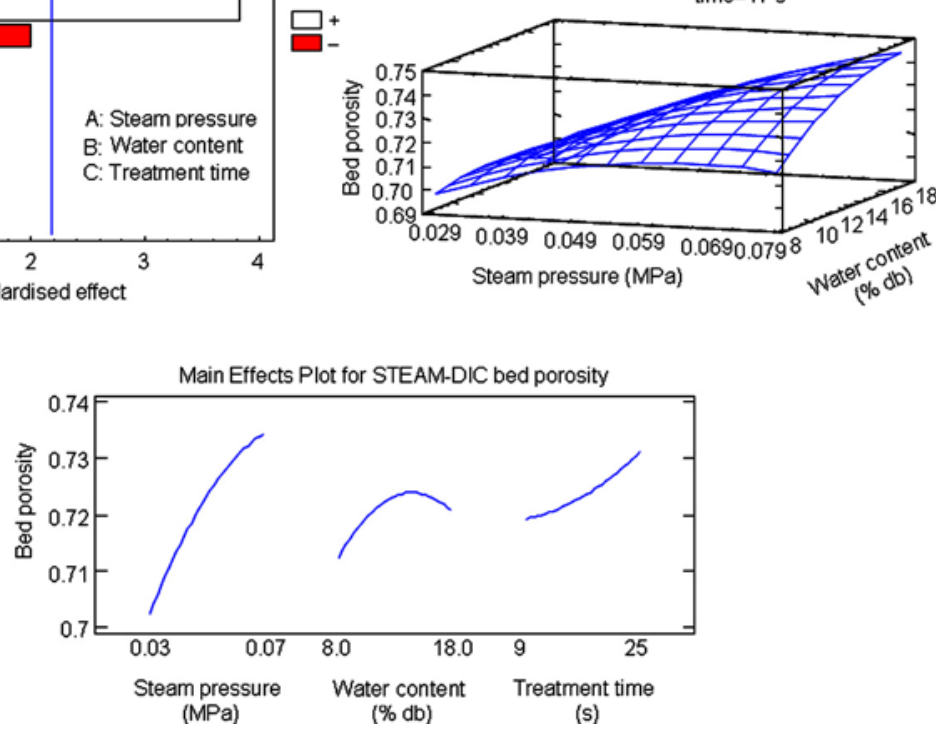

Figure 7. Porosity of SMP: (a) HAP-DIC textured powder and (b) STEAM-DIC textured powder. 

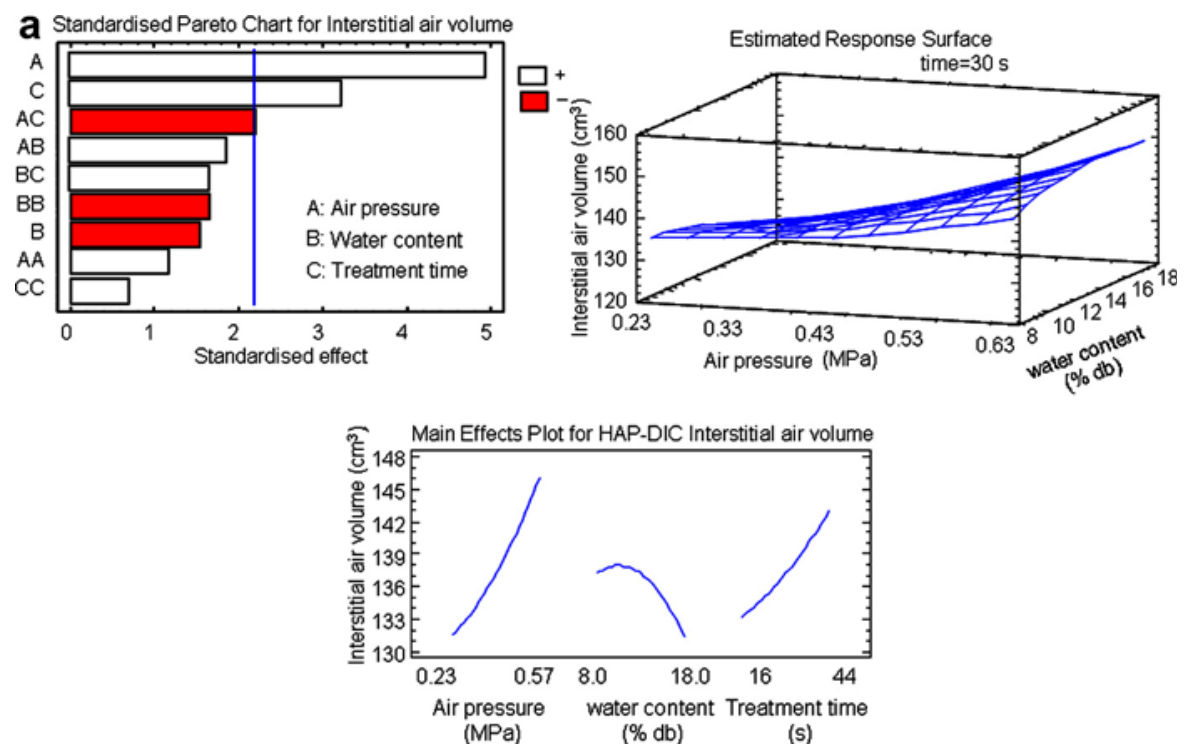

b Standardised Pareto Chart for Interstitial air volume
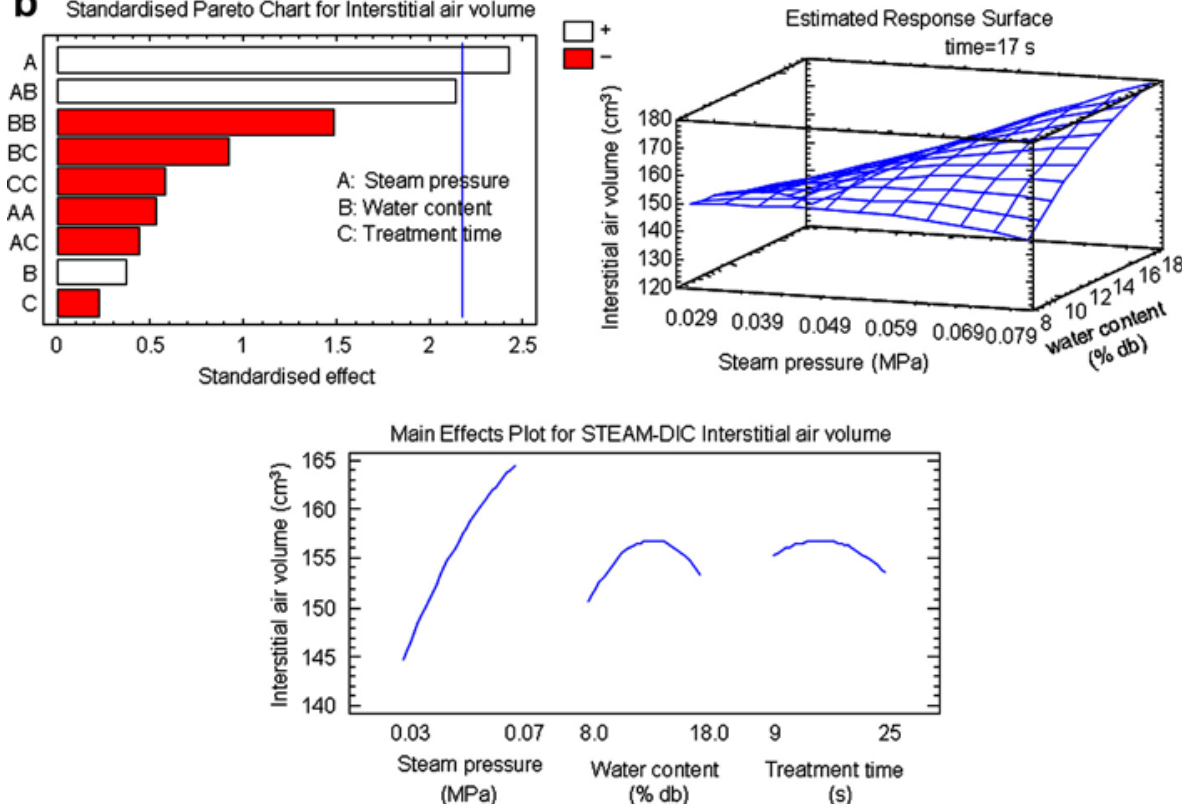

Figure 8. Interstitial air volume of SMP: (a) HAP-DIC textured powder and (b) STEAM-DIC textured powder. 
Table V. Compressibility, volume of interstitial air, and porosity of SMP: DIC-texturing powder, rewetted powder, and classical spray-dried powder.

\begin{tabular}{lccc}
\hline SMP & $\chi(\%)$ & $V_{\mathrm{ai}}\left(\mathrm{cm}^{3} \cdot 100 \mathrm{~g}^{-1}\right)$ & $\varepsilon(\%)$ \\
\hline Classical spray-dried powder (control) & 9.9 & 138.3 & 69 \\
Rewetted powder at $W=13 \% \mathrm{db}$ & 3.43 & 135.9 & 67 \\
HAP-DIC powder $P=0.57 \mathrm{MPa} ; W=8 \% \mathrm{db} ; t=44 \mathrm{~s}$ & 13.17 & 149 & 71 \\
HAP-DIC powder $P=0.57 \mathrm{MPa} ; W=18 \% \mathrm{db} ; t=16 \mathrm{~s}$ & 14.47 & 144.5 & 71 \\
STEAM-DIC powder $P=0.050 \mathrm{MPa} ; W=13 \% \mathrm{db} ; t=17 \mathrm{~s}$ & 26.2 & 146 & 75 \\
\hline
\end{tabular}

for HAP-DIC texturing (with $R^{2}=0.70$ ) and for STEAM-DIC texturing (with $R^{2}=0.68$ ), as follows:

HAP-DIC:

$$
\begin{aligned}
\text { Porosity }= & 0.7001-0.07 P-0.0013 \mathrm{~W} \\
& -0.0005 t+0.11 P^{2} \\
& -0.0015 P W+0.0016 P t \\
& +0.0001 W^{2}
\end{aligned}
$$

\section{STEAM-DIC:}

$$
\begin{aligned}
\text { Porosity }= & 0.656+1.03 P+0.0029 W \\
& -0.001 t-12.1 P^{2} \\
& +0.075 P W-0.0003 W^{2} \\
& +0.00006 W t+0.00003 t^{2}
\end{aligned}
$$

The interstitial air volume $V_{\text {ai }}$ translates the tapped bed porosity of powder. The results obtained (Figs. 8a and 8b) revealed pressure as the most influencing parameter, whatever the version of DIC-texturing (HAP-DIC or STEAM-DIC). It was interesting to note that the compressibility, porosity, and volume of interstitial air decreased after SMP had been rewetted (Tab. V).

It was significant that in the case of HAP-DIC, the treatment time also had a significant effect: the volume of the interstitial air was $V_{\mathrm{ai}}=149$ and $178 \mathrm{~cm}^{3} \cdot 100 \mathrm{~g}^{-1}$ for powder textured with $(P=0.57 \mathrm{MPa}$;
$W=18 \% \mathrm{db} ; t=16 \mathrm{~s})$, and with $(P=$ $0.070 \mathrm{MPa} ; W=18 \% \mathrm{db} ; t=19 \mathrm{~s})$, respectively, whereas the volume of the interstitial air was 135.9 and $138.3 \mathrm{~cm}^{3} \cdot 100 \mathrm{~g}^{-1}$ for rewetted and conventional spray-dried SMP, respectively.

However, we observed a slight decrease in $V_{\text {ai }}$ under some operating conditions of STEAM-DIC, such as $(P=0.030 \mathrm{MPa}$; $W=18 \% \mathrm{db} ; t=25 \mathrm{~s})$ and $(P=0.020 \mathrm{MPa}$; $W=13 \% \mathrm{db} ; t=17 \mathrm{~s})$, where $V_{\mathrm{ai}}=125.2$ and $129.6 \mathrm{~cm}^{3} \cdot 100 \mathrm{~g}^{-1}$, respectively; this decrease may be due to the friability and fragility of particles producing fines, which would subsequently fill the large interstices, reducing their number.

The regression model of the interstitial air volume of textured powder was determined for HAP-DIC texturing (with $R^{2}=0.81$ ), as follows:

$$
\begin{aligned}
V_{\mathrm{ai}}= & 130-2.4 P-0.77 W+0.19 t \\
& +54.7 P^{2}+4.4 P W-1.9 P t \\
& -0.12 W^{2}+0.05 W t+0.005 t^{2} .
\end{aligned}
$$

But in the case of STEAM-DIC, the regression model of interstitial air volume was given with $R^{2}=0.55$ :

$$
\begin{aligned}
V_{\mathrm{ai}}= & 106-124.3 P+1.8 W+3.4 t \\
& -5674.4 P^{2}+109.7 P W-14.0 P t \\
& -0.19 W^{2}-0.12 W t-0.04 t^{2} .
\end{aligned}
$$


a Standardised Pareto Chart for HAP-DIC specific area
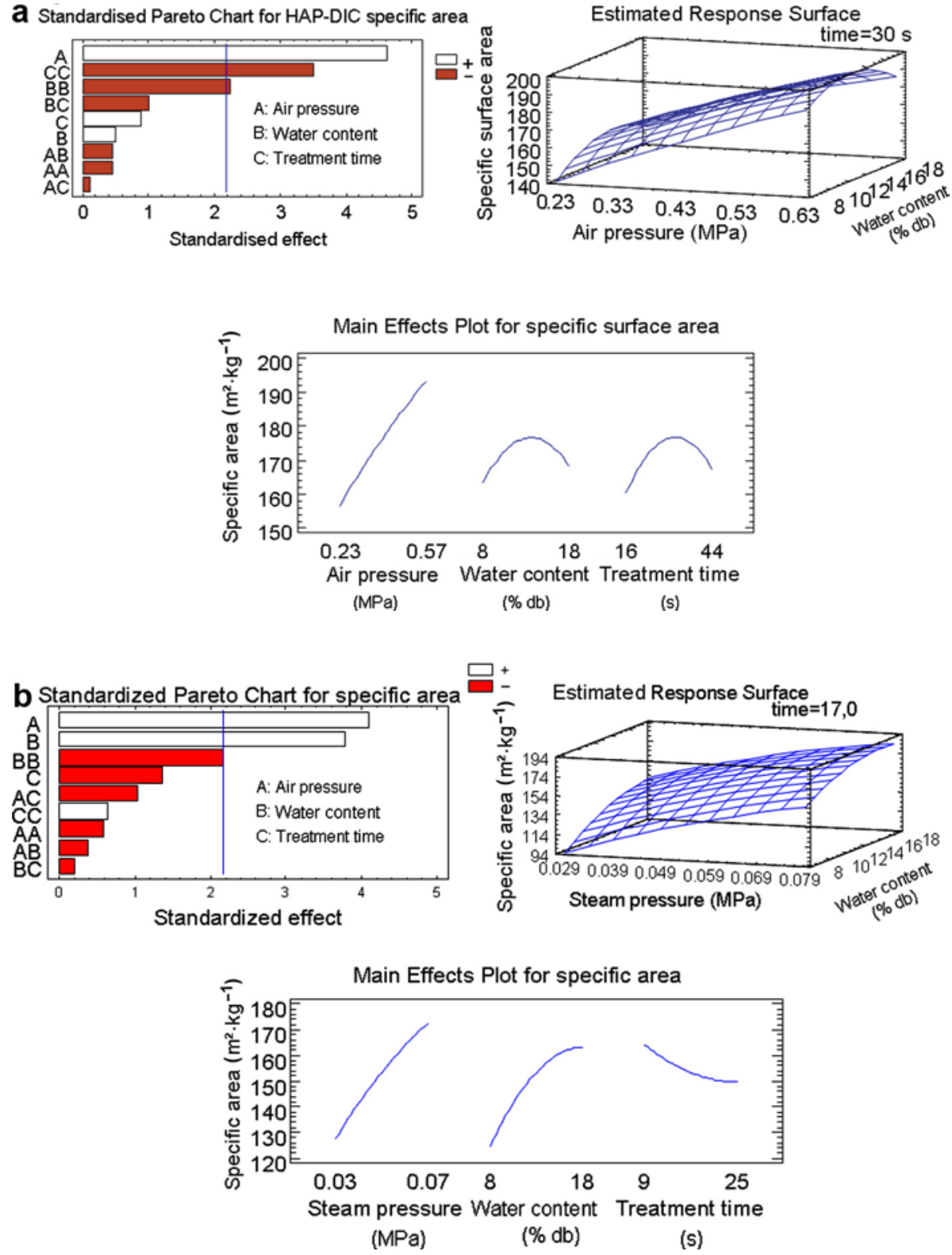

Figure 9. Impact of air and steam pressure, respectively (expressed in $\mathrm{MPa}$ ), of initial water content $(\% \mathrm{db})$ and of treatment time (in seconds) in the texturing by HAP-DIC and STEAM-DIC, respectively, on SSA of SMP. 
Figures $9 \mathrm{a}$ and $9 \mathrm{~b}$ show the SSA of skim milk against operative HAP-DIC and STEAM-DIC parameters, respectively. Whatever the DIC version, the pressure had a significant effect: the higher the pressure, the higher the SSA. The initial water content of skim milk had a negligible effect in the case of HAP-DIC, as did the treatment time in the case of STEAM-DIC.

Under some treatment conditions (such as HAP-DIC: $P=0.57 \mathrm{MPa}, W=18 \% \mathrm{db}$, $t=16 \mathrm{~s} ; \quad P=0.57 \mathrm{MPa}, \quad W=18 \% \mathrm{db}$, $t=44 \mathrm{~s}$ and STEAM-DIC: $P=50 \mathrm{kPa}$, $W=13 \% \mathrm{db}, \quad t=17 \mathrm{~s} ; \quad P=70 \mathrm{kPa}$, $W=18 \% \mathrm{db}, t=9 \mathrm{~s}$; and $P=0.8 \mathrm{MPa}$, $W=13 \% \mathrm{db}, t=17 \mathrm{~s}$ ), the SSA of powders could increase twice as much as that of conventional spray-dried powders to around $200 \mathrm{~m}^{2} \cdot \mathrm{kg}^{-1}$ versus $109 \mathrm{~m}^{2} \cdot \mathrm{kg}^{-1}$.

The HAP-DIC regression model was given with $R^{2}=0.79$ :

$$
\begin{aligned}
\mathrm{SSA}= & -68+19.9 P+15.1 W+5.2 t \\
& -0.67 P^{2}-0.29 P W-0.02 P t \\
& -0.43 W^{2}-0.08 W t-0.06 t^{2}
\end{aligned}
$$

The STEAM-DIC regression model was given with $R^{2}=0.77$ :

$$
\begin{aligned}
\mathrm{SSA}= & -67.2+301.7 P+15.6 \mathrm{~W} \\
& -0.14 t-82.6 P^{2}-2.5 P W \\
& -4.4 P t-0.38 W^{2} \\
& -0.03 W t+0.05 t^{2} .
\end{aligned}
$$

Observations of ultra-structure were carried out using a scanning electron microscope. Figure 10 shows the impact of HAP-DIC and STEAM-DIC on the microstructure of SMPs. DIC-texturing enabled the granule structure, which was initially extremely compact, to become porous.

The textural characteristics of the powders are correlated with bulk density, SSA, and functional behaviour. The different ultra-structures observed in SMPs, both before and after DIC-texturing, are reflected in their physical, technological, flow, and functional properties such as rehydration capacity and kinetics, poor wettability, and so on. It is of interest that the rewetting process causes some physical changes in the powder, such as lactose crystallization on the surface of the particles; this phenomenon is noticed at high levels of water content (i.e. $18 \% \mathrm{db}$ and $22 \% \mathrm{db}$ ). However, this effect would not be seen when DIC treatment is directly inserted in conventional spray drying with intervention just before the final stage of drying.

\subsection{Analysis of reconstitution properties}

The results obtained (Tab. VI) with DICtextured SMP show an improvement in wettability, solubility, and dispersibility, which normally decrease after the rewetting process. Overall, DIC-textured powder had low dispersibility because the particles became expanded and brittle and therefore easy to break down by friction. It is generally noted that the larger the dry milk particles, the better the dispersibility, but apparently there are some exceptions. Konstance et al. [9] demonstrated that very large particles of foam spray-dried milk had less dispersibility than small ones. Particles with average diameters above $710 \mu \mathrm{m}$ showed a linear relationship with dispersibility. Dustiness and floodability were interrelated. High dispersibility of powder was correlated with the free flow properties of fine powder.

Under certain conditions of HAP-DIC $(P=0.57 \mathrm{MPa} ; W=8 \% \mathrm{db} ; t=44 \mathrm{~s})$, the reconstitution properties had the same value as the conventional spray-dried SMP, with a very slight increase in dispersibility after decreasing the dispersibility and solubility index due to the rewetting operation. However, the STEAM-DIC SMP $(P=0.020 \mathrm{MPa} ; \quad W=13 \% \mathrm{db} ; \quad t=17)$ 

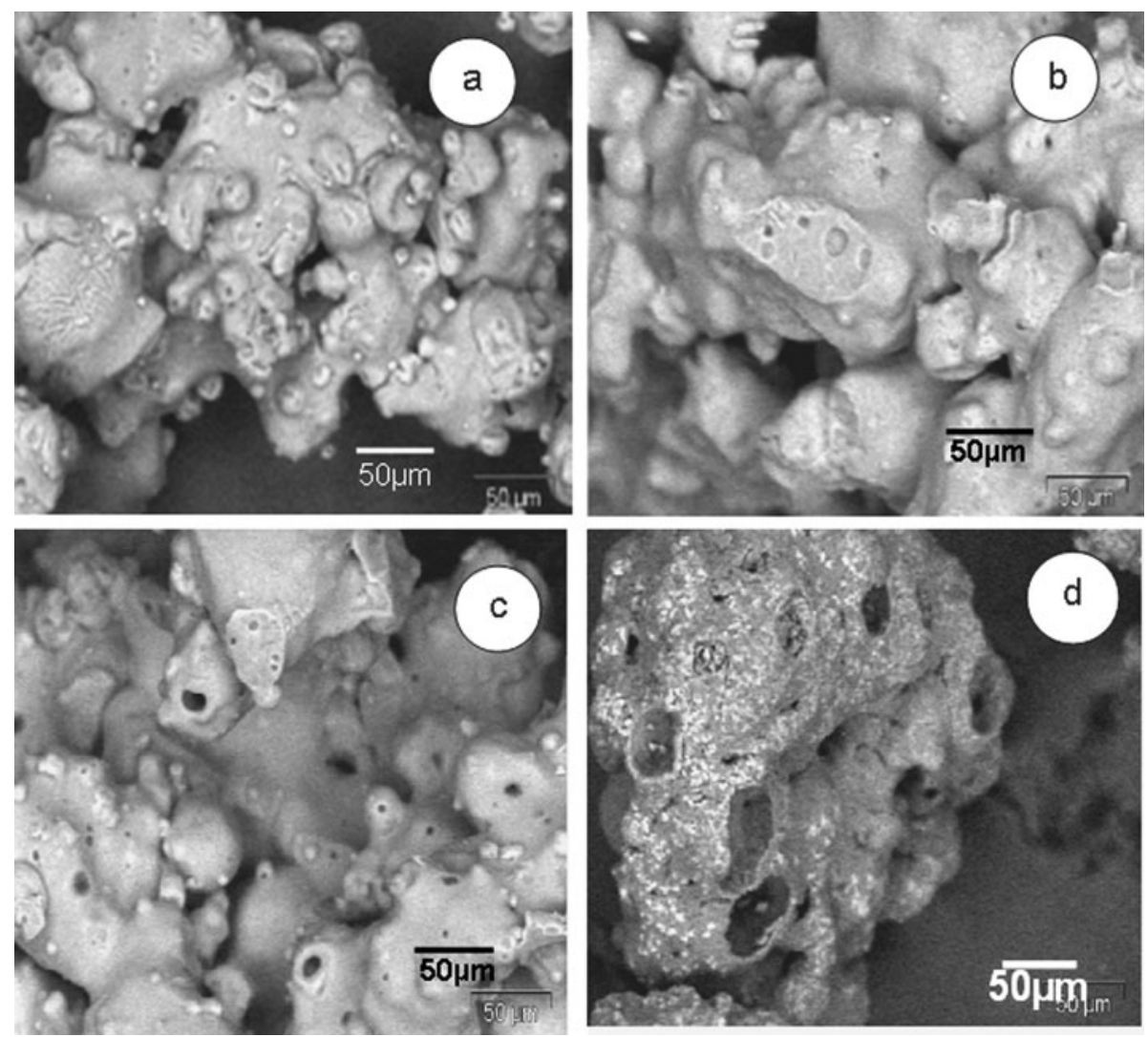

Figure 10. Microstructure of SMP granules: (a) conventional spray-dried SMP (4\% db); (b) spraydried skim milk rewetted at $18 \% \mathrm{db}$; (c) HAP-DIC expanded granule spray-dried SMP textured at $P($ air pressure $)=0.57 \mathrm{MPa} ; W=8 \% \mathrm{db} ; t$ (treatment time) $=44 \mathrm{~s}$; and (d) STEAM-DIC expanded granule spray-dried SMP textured at $P$ (steam pressure) $=0.07 \mathrm{MPa} ; W=18 \% \mathrm{db}$; $t$ (thermal treatment time) $=9 \mathrm{~s}$.

Table VI. Reconstitution properties of SMP: DIC-texturing powder, rewetted powder, and classical spray-dried powder.

\begin{tabular}{lccc}
\hline SMP & $\begin{array}{c}\text { Solubility } \\
\text { index (\%) }\end{array}$ & $\begin{array}{c}\text { Wettability } \\
\text { index (s) }\end{array}$ & $\begin{array}{c}\text { Dispersibility } \\
\text { index (\%) }\end{array}$ \\
\hline Classical spray-dried powder (control) & 100 & $>120$ & 79 \\
Rewetted powder at $W=13 \% \mathrm{db}$ & 72 & 4 & 50 \\
$\begin{array}{l}\text { HAP-DIC powder } P=0.57 \mathrm{MPa} ; \\
W=8 \% \mathrm{db} ; t=44 \mathrm{~s}\end{array}$ & 100 & $>120$ & 81 \\
$\begin{array}{l}\text { STEAM-DIC powder } P=0.020 \mathrm{MPa} ; \\
\text { z } W=13 \% \mathrm{db} ; t=17 \mathrm{~s}\end{array}$ & 98.5 & 4 & 79 \\
\hline
\end{tabular}


presented better reconstitution properties than the rewetted one. STEAM-DIC textured powder solubility and dispersibility were $98.5 \%$ and $79 \%$, respectively, versus $72 \%$ and $50 \%$ for rewetted SMP at $W=13 \% \mathrm{db}$.

In order to get the best dispersibility, it is advised that the milk powder particle size should range mainly between 90 and $250 \mu \mathrm{m}$. Only $<20 \%$ particles may be below $90 \mu \mathrm{m}$ [12], with an absence of particles with diameters higher than $250 \mu \mathrm{m}$ [18]; the optimal value of average particle diameter would be $200 \mu \mathrm{m}$ [7].

The wettability of SMP was improved after rewetting and DIC-texturing under optimized conditions. The tendency of milk powder to form lumps throughout the water indicates poor wettability. Small particle size and symmetrical shape enhance the close packing of particles and thus inhibit penetration of the water. In general, the larger the particles and the more irregular the shape, the more interstices for wetting. Particle size affects the solubility rate. Large particles may sink, whereas small ones generally float on water, leading to uneven wetting and reconstitution [19]. By increasing the size of the particles by expanding them and by inducing large spaces among them, DIC-texturing also favoured wetting.

More uniformity of large particles results in fewer fines to fill in adjacent spaces, which restrains wetting. But in contrast, poor wettability may result in physical changes such as lactose crystals reacting as a water barrier and preventing the penetration of water. On the other hand, the presence of occluded air within the particles contributes to their tendency to float on the water's surface.

The solubility of powder may also be correlated with the degree of denaturation of proteins. In the case of STEAM-DIC, solubility was usually lower than for conventional spray-dried SMP. Texturing by steam implied some irreversible thermal changes such as denaturation, aggregation, and the breaking up of the globular materials (whey proteins) because of the thermal-hydromechanical effect of the pressure drop.

\section{CONCLUSION}

The results obtained prove that the instant controlled pressure-drop (DIC) treatment can greatly affect the physical, structural, and textural properties of spray-dried skim milk by texturing the powder granule. Whatever the DIC version (HAP-DIC or STEAM-DIC), the specific quality and properties of milk powders can be modified and controlled, depending on producer and consumer needs, by mastering the microstructure; DIC can allow the SSA to increase (reaching $200 \mathrm{~m}^{2} \cdot \mathrm{kg}^{-1}$ instead of $100 \mathrm{~m}^{2} \cdot \mathrm{kg}^{-1}$ for normally spray-dried powder) and allow the porosity, interstitial air volume and compressibility, dispersibility, and bulk density to decrease. Such properties are important in tabletting (e.g. coffee milk tablets and in the pharmaceutical industry).

Finally, it would be very interesting to study the impact of DIC treatment just after the spray drying of powder at different water contents instead of carrying out rewetting of the spray-dried powder $(4 \% \mathrm{db})$.

\section{REFERENCES}

[1] Al Haddad M., Al Mounir S., Sobolik V., Allaf K., Fruits \& vegetables drying combining hot air, DIC technology and microwaves, Int. J. Food Eng. 4 (2008) Article 9.

[2] Al-Kahtani H.A., Hassan B.H., Spray drying of Roselle (Hibiscus sabdariffa L.) extract, J. Food Sci. 55 (1990) 1073-1076.

[3] Allaf K., Louka N., Parent F., Bouvier J.M., Forget M., Method for processing phytogenic materials to change their texture, apparatus therefor, and resulting materials, Patent WO6504466(A1), 1995.

[4] Allaf K., Vidal P., Feasibility study of a new process of swell-drying by instant 
decompression toward vacuum of in pieces vegetables in view of a rapid re-hydration, Gradient Activity Plotting, Université Technologique de Compiègne, France, UTC $\mathrm{N}^{\circ} \mathrm{CR} / 89 / 103,1988$.

[5] Barbosa-Canovas G.V., Malave-Lopez J., Peleg M., Density and compressibility of selected food powders mixture, J. Food Proc. Eng. 10 (1987) 1-19.

[6] Carr R.L. Jr., Evaluation flow properties of solids, Chem. Eng. 72 (1985) 163-168.

[7] Cayot P., Lorient D., Structures et technofonctions des protéines du lait, Tec et Doc, Lavoisier, Paris, France, 1998.

[8] FIL, Lait sec - Détermination du taux d'humidité, méthode de référence. Norme 26A, Fédération Internationale de Laiterie, Bruxelles, Belgique, 1993.

[9] Konstance R.P., Onwulata C.I., Holsinger V.H., Flow properties of spray-dried encapsulated butteroil, J. Food Sci. 60 (1995) 841-844.

[10] Krokida M.K., Maroulis Z.B., Effect of drying method on shrinkage and porosity, Dry. Technol. 15 (1997) 2441-2458.

[11] Krokida M.K., Zogzas N.P., Maroulis Z.B., Shrinkage and porosity during drying. Modelling the effect of vacuum, Int. J. Food Sci. Technol. 32 (1998) 445-458.

[12] Lascelles D.R., Baldwin A.J., Dispersibility of whole milk powder in warm water, N. Z. J. Dairy Sci. 38 (1979) 351-360.

[13] Masters K., Spray drying fundamentals: process stages and layouts, in: Masters $\mathrm{K}$. (Ed.), Spray Drying Handbook, Halsted Press, New York, USA, 1979, pp. 21-53.

[14] Masters K., Drying of droplets/sprays, in: Masters K. (Ed.), Spray Drying Handbook, Halsted Press, New York, USA, 1979, pp. 291-335.

[15] Mounir S., Allaf K., Definition of threestage spray drying by inserting the instant controlled pressure drop (DIC) technology in the classical spray-drying process, Dry. Technol. 26 (2008) 452-463.

[16] Nath S., Satpathy G.R., A systematic approach for investigation of spray drying processes, Dry. Technol. 16 (1998) 1173-1193.

[17] Niro Atomizer, Analytical methods for dry milk products, 4th edn., GEA NIRO, Copenhagen, Denmark, 1978. Available at: http:/www.niro.com/NIRO/CMSDoc.nsf/ WebDoc/ndkw6dknxs [accessed on 03/ 03/2010].

[18] Pisecky J., Standards, specifications and test methods for dry milk products, in: MacCarthy D. (Ed.), Concentration and Drying of Foods, Elsevier, London, UK, 1986, pp. 203-220.

[19] Potter N.N., Food Science, AVI Publishing, Westport, Connecticut, USA, 1968, pp. 227257.

[20] Walton D.E., The morphology of spray-dried particles: a qualitative view, Dry. Technol. 18 (2000) 1943-1986.

[21] Walton D.E., Mumford C.J., The morphology of spray-dried particles - the effect of process variables upon the morphology of spray-dried particles, Trans. Inst. Chem. Eng. Lond. 77 (1999) 442-460.

\section{Nomenclature}

DIC

$\varepsilon \quad$ Bed porosity (\%)

HAP-DIC High air pressure DIC

$P \quad$ Air or steam pressure in HAP-DIC treatment or in STEAM-DIC treatment, respectively $(\mathrm{MPa})$

$\rho_{\mathrm{a}} \quad$ Apparent or bulk density $\left(\mathrm{kg} \cdot \mathrm{m}^{-3}\right)$

$\rho_{\mathrm{p}} \quad$ Packed density $\left(\mathrm{kg} \cdot \mathrm{m}^{-3}\right)$

$\rho_{\text {int }} \quad$ Intrinsic (true or skeletal) density $\left(\mathrm{kg} \cdot \mathrm{m}^{-3}\right)$

SMP Skim milk powder

SSA Specific surface area $\left(\mathrm{m}^{2} \cdot \mathrm{kg}^{-1}\right)$

\section{STEAM-}

DIC Steam pressure DIC

$t \quad$ DIC processing time (s)

$V_{\text {ai }} \quad$ Interstitial air volume $\left(\mathrm{cm}^{3}\right.$ for $\left.100 \mathrm{~g}\right)$

$W \quad$ Moisture content of powder just before DIC treatment (g water $100 \mathrm{~g}^{-1}$ dry matter, expressed as \% db: percentage dry basis) $\chi \quad$ Compressibility (\%) 